\title{
Front Matter: Volume 11705
}

, "Front Matter: Volume 11705," Proc. SPIE 11705, Novel In-Plane Semiconductor Lasers XX, 1170501 (16 April 2021); doi: 10.1117/12.2596668

SPIE. Event: SPIE OPTO, 2021, Online Only 


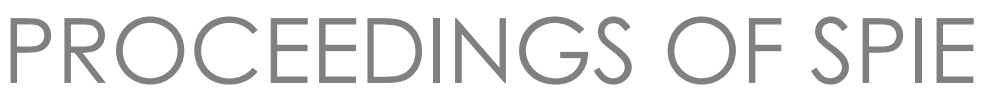

\section{Novel In-Plane Semiconductor Lasers $X X$}

Alexey A. Belyanin

Peter M. Smowton

Editors

6-11 March 2021

Online Only, United States

Sponsored and Published by

SPIE 
The papers in this volume were part of the technical conference cited on the cover and title page. Papers were selected and subject to review by the editors and conference program committee. Some conference presentations may not be available for publication. Additional papers and presentation recordings may be available online in the SPIE Digital Library at SPIEDigitalLibrary.org.

The papers reflect the work and thoughts of the authors and are published herein as submitted. The publisher is not responsible for the validity of the information or for any outcomes resulting from reliance thereon.

Please use the following format to cite material from these proceedings:

Author(s), "Title of Paper," in Novel In-Plane Semiconductor Lasers XX, edited by Alexey A. Belyanin, Peter M. Smowton, Proceedings of SPIE Vol. 11705 (SPIE, Bellingham, WA, 2021) Seven-digit Article CID Number.

ISSN: 0277-786X

ISSN: 1996-756X (electronic)

ISBN: 9781510642454

ISBN: 9781510642461 (electronic)

Published by

SPIE

P.O. Box 10, Bellingham, Washington 98227-0010 USA

Telephone +1 3606763290 (Pacific Time) · Fax +1 3606471445

SPIE.org

Copyright (c) 2021, Society of Photo-Optical Instrumentation Engineers.

Copying of material in this book for internal or personal use, or for the internal or personal use of specific clients, beyond the fair use provisions granted by the U.S. Copyright Law is authorized by SPIE subject to payment of copying fees. The Transactional Reporting Service base fee for this volume is $\$ 21.00$ per article (or portion thereof), which should be paid directly to the Copyright Clearance Center (CCC), 222 Rosewood Drive, Danvers, MA 01923. Payment may also be made electronically through CCC Online at copyright.com. Other copying for republication, resale, advertising or promotion, or any form of systematic or multiple reproduction of any material in this book is prohibited except with permission in writing from the publisher. The CCC fee code is $0277-$ $786 \mathrm{X} / 21 / \$ 21.00$.

Printed in the United States of America by Curran Associates, Inc., under license from SPIE.

Publication of record for individual papers is online in the SPIE Digital Library.

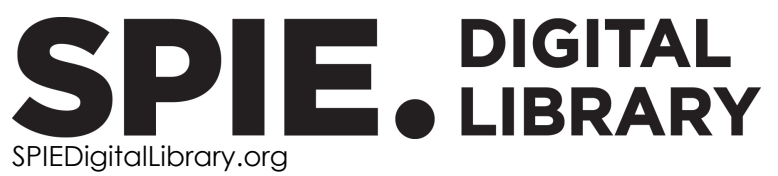

Paper Numbering: Proceedings of SPIE follow an e-First publication model. A unique citation identifier (CID) number is assigned to each article at the time of publication. Utilization of CIDs allows articles to be fully citable as soon as they are published online, and connects the same identifier to all online and print versions of the publication. SPIE uses a seven-digit CID article numbering system structured as follows:

- The first five digits correspond to the SPIE volume number.

- The last two digits indicate publication order within the volume using a Base 36 numbering system employing both numerals and letters. These two-number sets start with $00,01,02,03,04$, 05, 06, 07, 08, 09, OA, OB ... 0Z, followed by 10-1Z, 20-2Z, etc. The CID Number appears on each page of the manuscript. 


\section{Contents}

MODE-LOCKING: COMBS

1170503 InAs/InP quantum dot coherent comb lasers and their applications in data centre and coherent communication systems (Invited Paper) [11705-1]

1170508 First demonstration of a hybrid integrated InP-Si $\mathrm{N}_{4}$ diode laser for broadband optical frequency comb generation [11705-48]

\section{MATERIAL AND DEVICE DEVELOPMENT}

$11705 \mathrm{OE} \quad$ On the carrier kinetics in $\mathrm{Al}(\mathrm{In}) \mathrm{GaN}$ quantum wells stressed by high current densities [1 1705-11]

\section{III-V ON SILICON LASERS}

$117050 \mathrm{~K}$ Impact of dislocation density on performance and reliability of $1.3 \mu \mathrm{m}$ InAs quantum dot lasers epitaxially grown on silicon [11705-17]

HIGH BRIGHTNESS / NARROW LINEWIDTH

$117050 \mathrm{M}$ Single-pass tapered semiconductor optical amplifiers and modules for efficient coherent beam combining (Invited Paper) [1 1705-19]

$11705 \mathrm{ON}$ Enhanced self-aligned structure for improved lateral brightness in $940 \mathrm{~nm}$ high-power broadarea diode lasers [1 1705-20]

$1170500 \quad$ Narrow spectral line-width 785 nm DBR tapered lasers with 7 W output power [11705-21]

MODELING OF QCLS AND THEIR FREQUENCY COMBS

$1170510 \quad$ Frequency modulated combs as extended nondispersive waves [1 1705-33]

MID-INFRARED QCLS: NEW MATERIALS, HIGH PERFORMANCE

1170515 Highly efficient long-wavelength infrared, step-tapered quantum cascade lasers [1 1705-38] 
1170516 Beam stability of buried-heterostructure quantum cascade lasers formed by ICP-etching and HVPE regrowth [11705-39]

MID-INFRARED AND THZ LASERS: NEW DESIGNS I

1170519 Waveguiding and dispersion properties of interband cascade laser frequency combs [11705-42]

POSTER SESSION

11705 1D Can photonic-CMOS quantum cascade lasers with built-in nonlinear optics replace multiple quantum well diode-based QCLs? Analysis of performance advantages and future outlook [11705-46]

11705 IE AIGalnAs / InP laser heterostructure improvement [1 1705-47] 